\title{
Production of Biofuels for transport in Colombia:
}

AN ASSESSMENT THROUGH SUSTAINABILITY TOOLS CARLOS ARIEL RAMÍREZ TRIANA
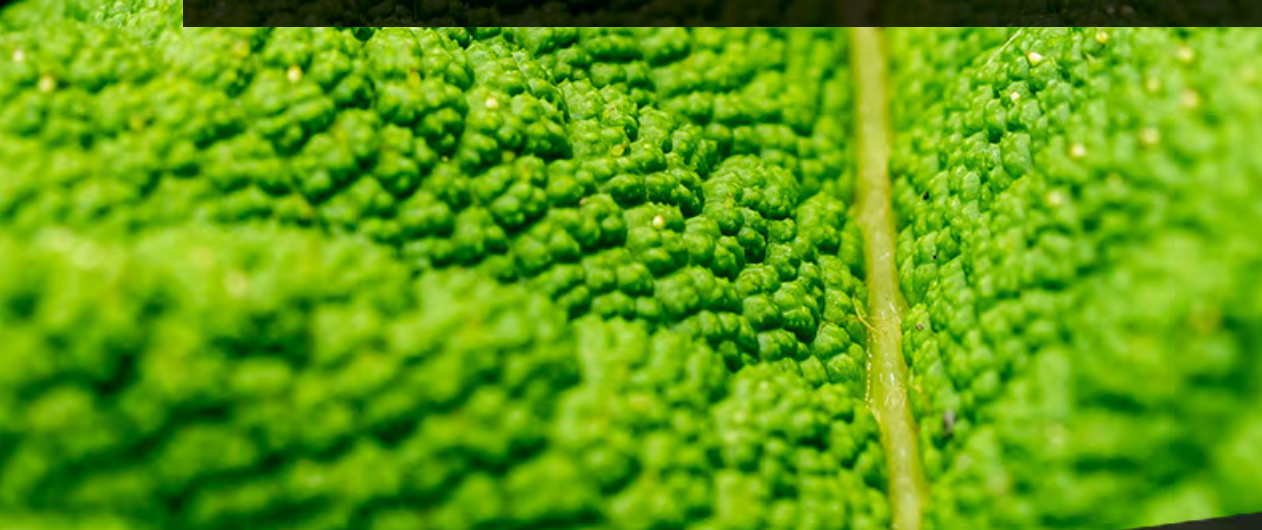



\title{
PRODUCTION OF BIOFUELS FOR TRANSPORT IN COLOMBIA:
}

\author{
AN ASSESSMENT THROUGH \\ SUSTAINABLITYY TOOLS
}

CARLOS ARIEL RAMÍREZ TRIANA BSC ECONOMICS. MSC ECONOMICS.

PHD CANDIDATE IN MAGEMENT

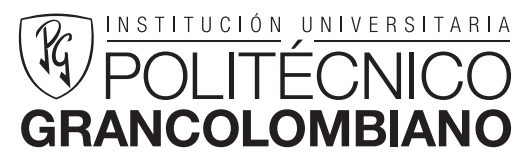




\section{GRANCOLOMBIANO}

INTITUCIÓN UNIVERSITARIA

POLITÉCNICO GRANCOLOMBIANO

Production of Biofuels for transport in Colombia:

An assessment through sustainability tools

E-ISBN: 978-958-872I-54-5

Octubre de 2017

Bogotá Colombia

\section{Rector}

Fernando Dávila Ladrón de Guevara

Vicerrector Académico

Juergen Chiari Escobar

Secretario General

Billy Escobar Pérez

Facultad de Ciencias Administrativas,

Económicas y Contables

\section{Decano}

Deisy de la Rosa Daza

Autor:

Carlos Ariel Ramírez Triana

Editorial Politécnico Grancolombiano

Av. Caracas No. 63-55

PBx: 7455555 ext. II7I

editorial@poligran.edu.co

\section{Coordinador Editorial}

Eduardo Norman Acevedo

\section{Analista de Producción Editorial}

Paulo Mora Noguera

\section{Diseño}

Santiago Arciniegas

¿Cómo citar este Libro?

Ramírez Triana, C. A. (2017), Production of Biofuels for transport in Colombia: An assessment through sustainability tools, Bogotá: Editorial Politécnico Grancolombiano.

La Editorial Politécnico Grancolombiano pertenece a la Asociación de Editoriales Universitarias de Colombia, ASEUC.

El contenido de esta publicación se puede citar o reproducir con propósitos académicos siempre y cuando se dé cuenta de la fuente o procedencia. Las opiniones expresadas son responsabilidad exclusiva del autor. 


\section{Contents}

Abstract

I Introductory chapter: bioenergy, sustainability and Colombia 25

I.I Bioenergy and sustainability: general overview . . . . . . . . 28

I.I.I Bioenergy situation in the global energy scenario . . . . . . 28

I.I.2 Bioenergy/biofuels production . . . . . . . . . . 32

I.2 Sustainable development and energy $\ldots \ldots \ldots \ldots$. . . . . . . 37

I.2.I Biomass production and sustainability . . . . . . . . . . 38

I.3 Life Cycle assessment (LCA) importance . . . . . . . . . . . . . 39

I.4 Colombia: country, energy needs, and bioenergy industry . . . . . . 4 4

I.4.I General Information . . . . . . . . . . . . . . . 4 4I

I.4.2 Energy Information . . . . . . . . . . . . . . . . 45

I.4.3 Biofuels in Colombia . . . . . . . . . . . . . . . . 46

I.5 Conclusions and general comments . . . . . . . . . . . . . 56

2 Biofuels in the world and the latin america (LAC) region 61

2.I Policies and regulation for biofuels implementation at a global level . . 62

2.I.I Main regulations . . . . . . . . . . . . . . . . 63

2.I.2 Trends in biofuel policies and regulation in Latin American and Caribbean countries . . . . . . . . . . . . . 68

2.I.3 International trade protocols . . . . . . . . . . . . . 82

2.I.4 Conclusions . . . . . . . . . . . . . . . . . . 85

3 Environmental problems in Colombia and their relationship with bioenergy production

3.I Loss of biodiversity and ecosystem base . . . . . . . . . . . . . . 90

3.I.I Geographic biodiversity . . . . . . . . . . . . . . . . . 92

3.I.2 Issues related with ecosystem diversity . . . . . . . . . . . 93 
3.I.3 Diversity of species and their problems ......... . 95

3.2 Land: degradation, pollution and inappropriate use . . . . . . . . . . 95

3.2.I Conflict over land use . . . . . . . . . . . . . . 996

3.2.2 Land degradation ... . . . . . . . . . . . . 99

3.2.3 Soil contamination . . . . . . . . . . . . . I00

3.3 Water pollution and inappropriate use ............. I02

3.3.I Water supply: related issues .............. I02

3.3.2 Water demand: related issues ............. I03

3.3.3 Water pollution in Colombia ............. I04

3.4 Air pollution . . . . . . . . . . . . . . . . I05

3.4.I Air pollution in the World and in Colombia . . . . . . . I05

3.4.2 Sources of air pollution and affected sectors in Colombia . . . I07

3.4.3 Consequences of air pollution in Colombia . . . . . . . . I09

3.4.4 Air management in Colombia and their problems . . . . . . I09

3.5 Climate change and climate variability . . . . . . . . . . . IIO

3.5.I Climate change and climate variability .......... IIO

3.5.2 Causes and forces of the Climate Change in Colombia and in the World . . . . . . . . . . . . . . . . . . III

3.5.3 Effects and consequences of climate change in the World and Colombia ...................... II2

3.5.4 Policy actions to tackle CC in the World and Colombia and their main obstacles . . . . . . . . . . . . . . II3

3.6 Deterioration of the environmental quality of the human habitat . . . I I 5

3.7 Conclusions . . . . . . . . . . . . . . . . . II6

4 Biofuel costs and price formation $\quad$ II9

4.I Biofuel production costs . . . . . . . . . . . . . I20

4.I.I Palm oil biodiesel cost . . . . . . . . . . I20

4.I.2 Sugarcane-based ethanol .............. I25

4.2 Conclusions . . . . . . . . . . . . . . . . I3I

5 Biofuel value chains and contractual relationships $\quad$ I33

5.I Feedstock production and commercialization . . . . . . . . . . . I34

5.I.I Land Use in Colombia and its relationship with bioenergy . . I34

5.1.2 Production of palm oil . . . . . . . . . . I37

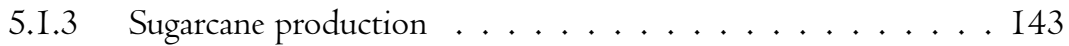

5.2 Agro-industrial transformations of feedstock . . . . . . . . . I5I

5.2.I Transformation of palm fruit into crude vegetable oil .... . I5I 
5.2.2 Transformation of crude palm oil into biodiesel . . . . . . . I55

5.2.3 Transformation of sugarcane and its apparent consumption . . . . . . . . . . . . . . I55

5.2.4 Transformation of sugarcane into ethanol . . . . . . . . I59

5.3 Distribution and commercialization . . . . . . . . . . . . I60

5.4 The consumer sector . . . . . . . . . . . . . . . I6I

5.4.I Projected consumption of biodiesel ........... I6I

5.4.2 Projected ethanol consumption . . . . . . . . . . I62

5.4.3 Current biofuel consumption ............. I65

6 Life cycle analysis - environmental study $\quad$ I67

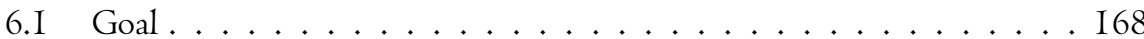

6.I.I Methodology of LCA . . . . . . . . . . . I68

6.1.2 Scope ............................ I69

6.I.3 Information for the inventory ............. I72

6.1.4 Assessment of the environmental impact . . . . . . . . I78

6.I.5 Interpretation . . . . . . . . . . . I78

6.I.6 Limitations of the study . . . . . . . . . . . . . . . I79

6.2 Inventory analysis . . . . . . . . . . . . . . . I80

6.2.1 Sugarcane crop .................. I80

6.2.2 Sugarcane processing plant (ingenio) and ethanol production . I95

6.2.3 Palm oil extraction and production of biodiesel . . . . . . 222

6.2.4 Transport to the service station . . . . . . . . . . 232

6.2.5 Transport of palm oil Biodiesel to California . . . . . . . 233

6.2.6 Use of fuels in vehicles . . . . . . . . . . . . . 233

6.2 .7 Fossil fuels . . . . . . . . . . . . . . 236

6.2 .8 Electricity production ................ 24I

6.3 Impacts Evaluation . . . . . . . . . . . . . . . . . 242

6.3.I Fossil fuels . . . . . . . . . . . . . . . . . 242

6.3.2 Sugarcane-based ethanol . . . . . . . . . . . . 245

6.3.3 Palm oil biodiesel .................. 248

6.3.4 Indirect land use changes (iLUC) . . . . . . . . . . . 252

6.3.5 Blending options and exports to California . . . . . . . . . 254

6.3.6 Comparison of Colombian biofuels with some other biofuels . 255

6.4 Discussion and conclusions . . . . . . . . . . . . . . . 257

6.4.I Sugarcane-based ethanol . . . . . . . . . . . . 258

6.4.2 Palm oil biodiesel ................ . . 261 
6.4.3 Final conclusions .................. 264

7 Biofuel value chains and contractual relationships $\quad 267$

7.I Aim of the study . . . . . . . . . . . . . . . . . . 268

7.2 Methodology . . . . . . . . . . . . . . . . 270

7.2.I Conceptual framework . . . . . . . . . . . . 270

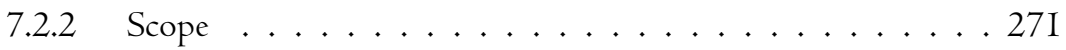

7.2.3 Limitations of this study . . . . . . . . . . . 27I

7.3 Biophysical aptitude . . . . . . . . . . . . . . . . . . . . . . . . . . . . . . . . . . . . . . . . . . .

7.3.I Climatic factors . . . . . . . . . . . . 274

7.3.2 Agronomic factors . . . . . . . . . . . . . 280

7.3.3 Agronomic suitability . . . . . . . . . . . . 290

7.3.4 Biophysical aptitude ............. . . 29I

7.3.5 Potential productivity . . . . . . . . . . . . 296

7.4 Legal restrictions . . . . . . . . . . . . . . . . . . . . 298

7.5 Ecologic limitations . . . . . . . . . . . . . . . . 300

7.5.I Greenhouse gases (GHG's) emissions . . . . . . . . . . 300

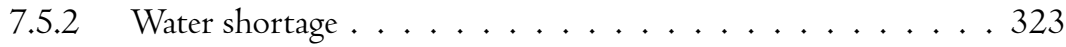

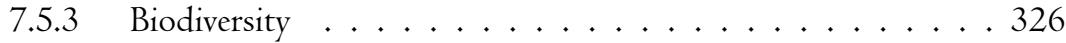

7.6 Socio-economic criteria . . . . . . . . . . . . . . . . . . . . . . . . . . . . . . . . . . . . . . . . . .

7.6.I Access to processing facilities . . . . . . . . . . . 328

7.6 .2 Access to markets . . . . . . . . . . . . . . 329

7.6.3 Access to road network ............... 330

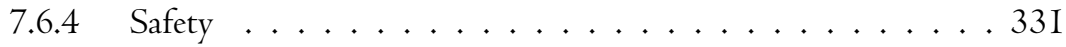

7.6.5 Food security . . . . . . . . . . . . . 332

7.7 Discussion and final remarks . . . . . . . . . . . . 333

7.7.I Palmoil . . . . . . . . . . . . . . 334

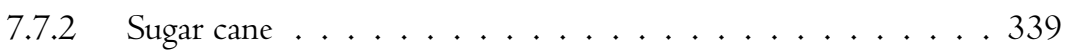

7.7.3 Stakeholders' engagement: contrast between the expansion potential in this study and former plans . . . . . . . . . 344

7.7.4 Conclusion ....................... 346

8 General conclusions $\quad 349$

9 Appendix 397

9.I Box I. Cassava-based ethanol innovative project . . . . . . . . . . . 398

9.2 Box 2. US-Colombia biofuels trade through a FTA:

A temporarily obstructed possibility . . . . . . . . . . . . 399 
9.3 Box 3. Eviction processes: Recent history in Colombia . . . . . . . . . 400

9.4 Endpoint and midpoint indicators . . . . . . . . . . . . . . 40I

9.5 Wasteson land (sugarcane) . . . . . . . . . . . . 4 I I

9.6 Description of the stages in the sugar production process in the sugar mill (ingenio) . . . . . . . . . . . . . . . . . 4I2

9.7 Transportation distances per every I00 tons of sugarcane . . . . . . 4I3

9.8 Emissions per I $\mathrm{kg}$ of bagasse combustion and per every $\mathrm{IOO}$ tons of sugarcane (kg unless indicated otherwise) . . . . . . . . . . . 4I4

9.9 Description of the ethanol manufacture process . . . . . . . . . . 4I5

9.I0 Water treatment mass balance . . . . . . . . . . . . . . . 4I6

9.I I Mass Balance for compost stage . . . . . . . . . . . . . . . 4I7

9.I2 Agrochemicals employed in different areas of the palm oil crop $(\mathrm{kg} / \mathrm{kg}$

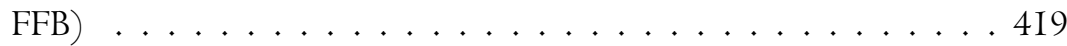

9.13 Description of the Palm oil process . . . . . . . . . . . . 420

9.I4 Air emissions as product of the combustion of I MJ of fiber, I MJ of shells per each 100 tons of FFB ( $\mathrm{kg}$ unless indicated otherwise) . . . . 42I

9.15 Waste waters treatment . . . . . . . . . . . . . . . 422

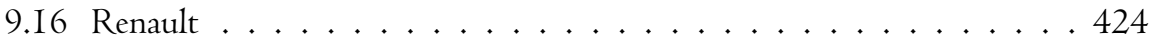

9.I7 Surface extension of the carbon zones $\left(\mathrm{km}^{2}\right)$, types of land use by vegetation zones in Colombia . . . . . . . . . . . . . . . 4 425

9.18 Map of natural potential vegetation . . . . . . . . . . . . . . . 426

9.19 Prospects of biofuels production in Colombia beyond first generation biofuels . . . . . . . . . . . . . . . . . . 4 427 



\section{List of Figures}

I.I World total renewable energy consumption . . . . . . . . . . 29

I.2 World renewable energy consumption by source . . . . . . . . . . 29

1.3 World Biomass energy consumption by sector . . . . . . . . 30

I.4 Route from biomass to biofuels . . . . . . . . . . . 33

I.5 Colombia's Oil production and consumption . . . . . . . . . 45

I.6 Colombia's Coal production and consumption . . . . . . . . . . 46

I.7 Land indicators of selected Comodities . . . . . . . . . . . . . 49

I.8 Production of selected Commodities in Colombia . . . . . . . . . 50

I.9 Yield of selected commodities in Colombia (tonnes/ha) . . . . 50

3.I Evolution of land use in Colombia . . . . . . . . . . . . . . 94

3.2 Land use in Colombia 2002 (Total II3'869.035 ha) . . . . . . 96

3.3 Land use in Colombia for Livestock growing purposes . . . . . . 97

4.I Palm oil production cost composition in colombia 2007 (by zones, COP\$) . . . . . . . . . . . . . . . I2I

4.2 Average Conformation of palm oil production costs (2007) . . . . I22

4.3 Production cost composition for a barrel of ethanol in different countries (2006) . . . . . . . . . . . . . I25

5.I Sugarcane production in Colombia . . . . . . . . . I45

5.2 Sugar exports in Colombia . . . . . . . . . . . . . I56

5.3 Sugar domestic consumption in Colombia and international price influence . . . . . . . . . . . . . . . . I57

5.4 Distribution and commercialization chains . . . . . . . . . I60

6.I Four key stages in a LCA, according ISO I4040 . . . . . . . I68

6.2 Studied areas for sugarcane and palm trees 2010 . . . . . . . . . I69

6.3 General overview of compared systems: Bioenergy and fossil energy . I7I

6.4 Inventory data sources for specific processes Specific data . . . . . I73

6.5 Illustration of the indirect land use change (iLUC) . . . . . I76 
6.6 Geographic location of the sugarcane plantation area . . . . . . . I80

6.7 Sugarcane crop cycle . . . . . . . . . . . . . . I83

6.8 Precipitation (left), Evaporation (right), in the geographic valley of Cauca River . . . . . . . . . . . . . . . . . I90

6.9 Irrigation channel in sugarcane plantations . . . . . . . . . . . I90

6.I0 Machinery and equipment used for land preparation . . . . . . . I92

6.I I Green manual harvest (on the left). Loading of cut sugarcane after pre-harvest burning (on the right) . . . . . . . . . I93

6.12 Ethanol production process in Colombia . . . . . . . . . I96

6.13 Sugarcane transformation process . . . . . . . . . . . . I98

6.I4 Illustration of the co-generation system applied within sugar mill

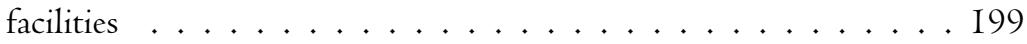

6.I5 Summary of the sugarcane-based ethanol manufacture process . . . 203

6.16 Residual Waters treatment . . . . . . . . . . . . . 206

6.17 Compost general process . . . . . . . . . . . . . . . . 208

6.I8 Mass flow of processing I00 tons of sugarcane for ethanol production 209

6.19 Prices of refined and white sugar . . . . . . . . . . . 212

6.20 Palm plantations in Colombia . . . . . . . . . . 213

6.2I Main cultivation zones for palm oil in Colombia 2008 . . . . . 2 I3

6.22 Palm tree. Different ages . . . . . . . . . . . 2 I5

6.23 Palm productivity in the study locations . . . . . . . . 2 I6

6.24 Chart on palm oil inventory process . . . . . . . . . . 216

6.25 From collecting task up to loading in trucks (palm oil) . . . . . . 2 I9

6.26 Transportation methods (palm oil) . . . . . . . . . . . 219

6.27 Transformation of land due to palm plantations (2000-2008) . . 220

6.28 Biodiesel production process . . . . . . . . . . . . 223

6.29 System characterization for palm oil extraction . . . . . . . . . 224

6.30 System characterization for palm oil refining process . . . . . . . 227

6.3I Mass flow for biodiesel production (per every I00 tons FFB) . . . . 230

6.32 Distance from Buenaventura port to Los Angeles . . . . . . . . . . 233

6.33 Distance from Santa Marta to Los Angeles . . . . . . . . . . . 233

6.34 Chart of the LCA for fossil fuels . . . . . . . . . . . . . 236

6.35 Loads to refinery and Barrancabermeja refining plant . . . . . . . 238

6.36 Sulphur content for Diesel (Colombia) . . . . . . . . . . . . 239

6.37 Crude oil supply to Californian refineries . . . . . . . . . . . . 240

6.38 GHG emissions for fossil fuels per MJ of fuel . . . . . . . . . . . . 243

6.39 GHG emissions for fossil fuels per v.km . . . . . . . . . . . . . 244 
6.40 Cumulative non-renewable energy demand per MJ of fossil fuel . . . 244

6.4I Cumulative non-renewable energy demand per v.km . . . . . . . . 245

6.42 Global warming potential of sugarcane ethanol in $\mathrm{CO} 2 \mathrm{eq} \mathrm{v} . \mathrm{km}$. . . 245

6.43 Global warming potential of sugarcane ethanol per MJ of fuel . . . 245

6.44 Global warming potential for sugar crop in CO2 eq per $\mathrm{Kg}$ of sugarcane 246

6.45 Global warming potential for sugar processing divided by process . . 246

6.46 Sensitivity analysis of the allocation method for ethanol . . . . . . 247

6.47 CED of sugarcane ethanol in MJ of non-renewable energy per MJ of fuel . . . . . . . . . . . . . . . . . . . 247

6.48 CED of sugarcane ethanol in MJ of non-renewable energy per v.km . 248

6.49 GWP for palm oil biodiesel in CO2 eq per v.km . . . . . . . . . 248

6.50 GWP for palm oil biodiesel by process in $\mathrm{g}$ of CO2 eq per MJ of fuel249

6.5I GWP for palm oil biodiesel in $\mathrm{kg} \mathrm{CO} 2 \mathrm{eq}$ per $\mathrm{kg}$ of Fresh Fruit Bunch 249

6.52 GWP for palm oil biodiesel divided by process . . . . . . . . . 250

6.53 GWP for average and optimized scenarios in comparison with fossil

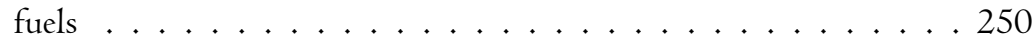

6.54 Sensitivity analysis of the allocation method for palm oil biodiesel . 250

6.55 CED for palm oil biodiesel in MJ of non-renewable energy per MJ

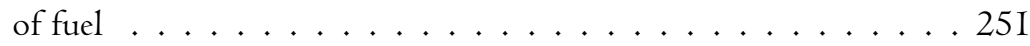

6.56 CED for palm oil biodiesel in MJ of non-renewable energy per v.km 252

6.57 Potential effects of iLUC caused by palm crops in Colombia . . . . 252

6.58 Potential effects of iLUC caused by sugarcane crops in Colombia . . 253

6.59 GWP for Ethanol (Colombian Average EIO EIO0). Ethanol used in Bogota and California . . . . . . . . . . . . . . . . 254

6.60 GWP for biodiesel (Colombian Average BIO BI00). Biodiesel used in Bogota and California . . . . . . . . . . . . . . 255

6.6I GWP of Colombian biofuels in comparison with other biofuels

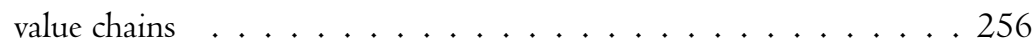

6.62 GWP of Colombian sugarcane based ethanol in comparison to

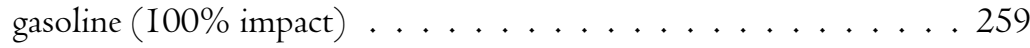

6.63 GWP of Colombian palm oil based biodiesel in comparison to diesel (I00\% impact) . . . . . . . . . . . . . . . 262

7.I Existing sugarcane crops (green) and palm oil crops (blue) in Colombia in the year 2008 . . . . . . . . . . . . . 269

7.2 General overview of the Geographic Information system GIS . . . . 270

7.3 Exclusion of zones regarding altitude, urban areas, and bodies of water 272 
7.4 General overview on employed biophysical criteria . . . . . . . . 273

7.5 Precipitation suitability map . . . . . . . . . . . . . . . . . . . 276

7.6 Temperature suitability map . . . . . . . . . . . . 278

7.7 Daily solar radiation, relative humidity, and wind speed . . . . . . 279

7.8 Climate conditions suitability map . . . . . . . . . . . . 280

7.9 Flooding suitability map . . . . . . . . . . . . . . 282

7.I0 Soil erosion suitability map . . . . . . . . . . . . . 283

7.I I Soil depth suitability map . . . . . . . . . . . . . . . 285

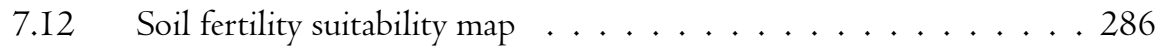

7.13 Drainage suitability map . . . . . . . . . . . . . . 288

7.14 Drainage suitability map . . . . . . . . . . . . . . . 289

7.I5 Agronomic suitability map . . . . . . . . . . . . . . 29I

7.I6 Biophysical factor suitability map for Palm oil crops . . . . . . . . . 292

7.17 Detailed biophysical suitability map . . . . . . . . . . . . 293

7.I8 FAO suitability map for palm oil crops . . . . . . . . . . . 293

7.I9 Biophysical factor suitability map for Sugarcane crops (left).

Detailed zoom in of the Cauca River Valley (blue: current sugarcane crops) (right) . . . . . . . . . . . . . . 295

7.20 FAO suitability map for sugarcane crops . . . . . . . . . . . . 296

7.2I Annual yields of sugarcane spotted in the sampled sites . . . . . . 297

7.22 Annual yields of Palm Oil in Colombia. (E) East (N) North (Center) 298

7.23 Map of legal restrictions . . . . . . . . . . . . . . . . 299

7.24 Forest ecosystems protected by the law . . . . . . . . . . . 300

7.25 Concept for modeling a GHG's emissions map . . . . . . . . . . 30 I

7.26 Soil carbon reserves . . . . . . . . . . . . . . . . . 302

7.27 Assessing model for calculating GHG's emissions due to $L U C$. . . 303

7.28 LUC from natural forest and agricultural land biofuel crops (palm) 303

7.29 Process to evaluate biomass carbon reserve for the reference use soil . 304

7.30 Map of reclassification of eco-zones by vegetation type and Map of land use defined by FAO and IPCC (left) and Map of land use (IGAC) 304

7.3I Total carbon biomass of the reference land use (in tons of carbon

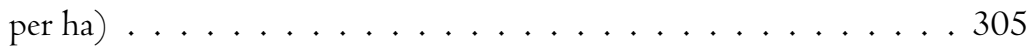

7.32 Cumulated biomass of palm oil (left) and sugarcane (right) . . . . 306

7.33 Process to evaluate biomass carbon reserve for the crops for bioenergy 306

7.34 Development of a simulated plant for the AGB of sugarcane in Brazil 307

7.35 Ratio Stem-root (based on dry weight) for sugarcane planted in pot 307

7.36 Potential change in the biomass reserves . . . . . . . . . . 308 
7.37 Assessment method for the change in Soil organic carbon . . . . . 309

7.38 Map of carbon reserve of a reference natural system . . . . . . . 3 IO

7.39 Relative Change factors of reserves (left) and $S O C_{0}$ for Colombia . $3 \mathrm{I} 2$

7.40 SOCt after land use change to palm (left) and sugarcane (right) . . . 3I3

7.4I SOC Change after turning the reference soil into palm oil crops (assessed in tons of $\mathrm{C}$ per ha) ................ 3I4

7.42 SOC Change after turning the reference soil into sugarcane crops (Assessed in tons of $\mathrm{C}$ per ha) ............ . . 3I4

7.43 Change in the carbon reserve due to $L U C$ from current use . . . 316

7.44 Change in carbon reserve due to current land use change to palm oil crops (tons of $\mathrm{CO} 2$ per $\mathrm{kg}$ of FFB) . . . . . . . . . . 316

7.45 Change in carbon reserve due to current land use change to sugarcane crops (tons of $\mathrm{CO} 2$ per $\mathrm{kg}$ of FFB) . . . . . . . . . 3 316

7.46 Relative GHG's emissions for palm oil-based biodiesel . . . . . . . 3 I8

7.47 Relative GHG's emissions for sugarcane-based ethanol . . . . . . . . 319

7.48 Carbon debt of palm oil-based biodiesel produced in Colombia [years] 32I

7.49 Carbon debt of sugarcane-based ethanol produced in Colombia [years]32 I

$7.50 \mathrm{Kg}$ of $\mathrm{CO} 2$ emitted per vehicle per $\mathrm{km} \ldots \ldots . \ldots 323$

$7.5 \mathrm{I}$ Hydric stress in Colombia . . . . . . . . . . . . . . . 324

7.52 Comparative Hydric stress Map for Colombia . . . . . . . . . . . . 325

7.53 Water use index in Colombia for a dry year . . . . . . . . . . 325

7.54 Priority conservation areas according to SINAP guidelines . . . . 326

7.55 Colombian forest areas . . . . . . . . . . . . . 327

7.56 Access to processing facilities . . . . . . . . . . . . . 328

7.57 Summary of the socio-economic factor taken into consideration . . . 328

7.58 Access to markets . . . . . . . . . . . . . . . . . 329

7.59 Access to main terrestrial roads and rivers . . . . . . . . . . . 330

7.60 Map of public security risk in Colombia . . . . . . . . . . . . 33 I

7.6I Map of current agricultural production . . . . . . . . . . 332

7.62 Palm oil suitability (I) . . . . . . . . . . 335

7.63 Palm oil suitability $(2) \ldots \ldots 335$

7.64 Palm oil suitability $(3) \ldots \ldots 336$

7.65 Palm oil suitability $(4) \ldots . \ldots . \ldots 336$

7.66 Zones with different suitability for palm oil plantations in Colombia

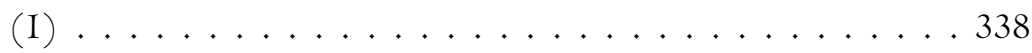

7.67 Zones with different suitability for palm oil plantations in Colombia

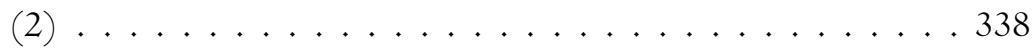


7.68 Sugarcane suitability (I) . . . . . . . . . . . . . . . . 339

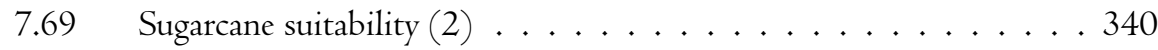

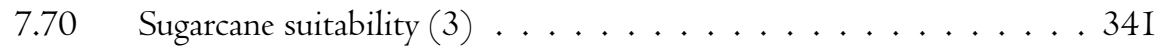

7.7I Sugarcane suitability $(4) \ldots \ldots \ldots \ldots$. . . . . . 34

7.72 Zones with different suitability for sugarcane plantation in Colombia (I) . . . . . . . . . . . . . . . . . . 342

7.73 Zones with different suitability for sugarcane plantations in Colombia (2) . . . . . . . . . . . . . . . . . . 343

9.I Comparison between standard vehicles (California vs Colombia) . . 404

9.2 Total environmental impact. Comparison between vehicles in California and Colombia . . . . . . . . . . . . . . . 405

9.3 Environmental impacts for ethanol . . . . . . . . . . . . 405

9.4 Environmental impacts for biodiesel . . . . . . . . . . . 406

9.5 Total environmental impact (Eco-indicator 99) for sugarcane-based ethanol . . . . . . . . . . . . . . . . . . 407

9.6 Total environmental impact (Eco-indicator 99) for palm oil-based biodiesel . . . . . . . . . . . . . . . . . 407 


\section{List of Tables}

I.I Colombian Population Distribution Estimated for 2006 and 2013 . 4I

I.2 Colombia Land distribution 2006 and 201 I . . . . . . . . . . 42

I.3 South American socioeconomic facts . . . . . . . . . . . . . . . . 42

I.4 Differences between Brazilian and Colombian ethanol industries . . 5I

2.I Biofuels domestic policies for USA, EU and LAC region . . . . . 85

5.I Current and forecasted land use in Colombia (Million ha) . . . . I I35

5.2 Sugarcane trade statistics for Colombia . . . . . . . . . . I58

5.3 Palm oil demand for biodiesel production . . . . . . . . . I6I

5.4 Ethanol production in Colombia (thousand liter) . . . . . . . I63

5.5 Sugarcane demand for bioethanol production .......... I63

6.I Emissions of NH3 - Mineral fertilizers (\% of $\mathrm{N}$ emitted in form of $\mathrm{NH} 3) \ldots \ldots \ldots \ldots \ldots \ldots$. . . . . . . . . . . . . . . . . . . . . .

6.2 Ethanol producing companies in Colombia . . . . . . . . I8I

6.3 Selection of agro-ecological zones .............. I8I

6.4 Identification of specific location (for ethanol production) . . . . . I82

6.5 General information on the studied location (for ethanol production) 183

6.6 Area and weighting factor within the selected studied locations . . . I83

6.7 Sugarcane crop cycle (Cauca Valley River) . . . . . . . . . . . . I85

6.8 Sugarcane Collection method within de geographic Valley of Cauca

River . . . . . . . . . . . . . . . . . I85

6.9 Sugarcane yield and sugar yield . . . . . . . . . . . . I87

6.10 Sugarcane yield for the assessed plantation sites . . . . . . . . . I87

6.I I Sugarcane inventory overview . . . . . . . . . . . . I87

6.I2 Fertilizer application in studied locations $(\mathrm{kg} / \mathrm{ha} / \mathrm{y}) \ldots$. . . . I88

6.I3 Recommended dose of fertilizers (N-P-K) for sugarcane crops. Assessment unit $\mathrm{kg} / \mathrm{ha} / \mathrm{y}$. . . . . . . . . . . . . . I89

6.I4 Pesticides application per year and hectare . . . . . . . . . I89 
6.I5 Water requirements for sugarcane using different irrigation systems

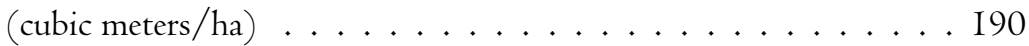

6.16 Energy requirement for land preparation in the sugarcane case . . . I92

6.I7 Energy consumption of the mechanic and manual harvesting process 193

6.I8 Transformation of the Land use and occupation of the sugarcane plantations within the studied locations . . . . . . . . . . . 194

6.I9 Emissions to the atmosphere from the burning process before

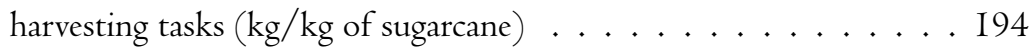

6.20 Emission to the atmosphere from fertilizers application $(\mathrm{kg} / \mathrm{kg}$ of sugarcane $\ldots \ldots \ldots \ldots \ldots$. . . . . . . . . . . . . . . . . . . . . . . . . .

6.2I Ethanol plants in Colombia 2009 . . . . . . . . . . . I95

6.22 Weighted average of production of different ethanol production

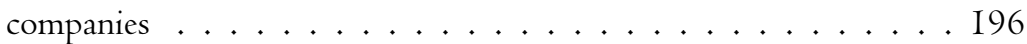

6.23 Mass flows and technologies for sugar and ethanol plants in Colombia 197

6.24 Material and energy consumption of the sugar processing factory per every IO0 tons of sugarcane . . . . . . . . . . . . I98

6.25 Properties of bagasse and charcoal . . . . . . . . . . . . 199

6.26 Summary of cogeneration processes of the different companies per IOO tons of processed sugarcane . . . . . . . . . . . . 200

6.27 Infrastructure of the sugar mill, furnace and turbine per every IOO tons of sugarcane . . . . . . . . . . . . 20I

6.28 Products and residuals from the sugar plant per every 100 tons of sugarcane (tons) . . . . . . . . . . . . . . . 202

6.29 Residuals from sugarcane per every I00 tons of sugarcane (tons) . . 203

6.30 Inputs and energy employed in the ethanol elaboration process $(\mathrm{kg}$ per $\mathrm{kg}$ of ethanol at 99,6\%, unless indicated otherwise) . . . . . 204

6.3 I Transportation distances for ethanol production . . . . . . . . . 205

6.32 Products, by-products, and residuals from the ethanol process (kg /

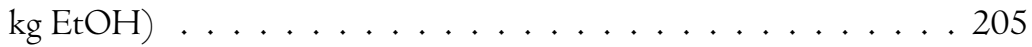

6.33 Allocation factors for the ethanol production (Average scenario) . . 210

6.34 Allocation factors for the ethanol production (Optimized scenario) . 2 I0

6.35 Economic values of the products of the sugar refinery and ethanol plant $(\mathrm{COP} / \mathrm{k}$ unless indicated otherwise $) \ldots . . . . . .2$ II

6.36 Energy value of the products and by-products of the sugar refinery and ethanol plant $(\mathrm{MJ} / \mathrm{k}$ unless indicated otherwise $) \ldots . . .2 \mathrm{I} 2$

6.37 Palm oil plantation and sampling areas (East, North and Central

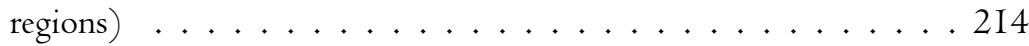


6.38 Annual yields of production per zone $($ ton $/$ ha $/ y) \ldots . . . .2$ I6

6.39 Inputs of mineral fertilizers for the different palm oil plantation zones $(\mathrm{kg} / \mathrm{ha} / \mathrm{y}) \ldots \ldots . \ldots . \ldots 217$

6.40 Nutrients composition in palm oil fruit residues in both wet and dry

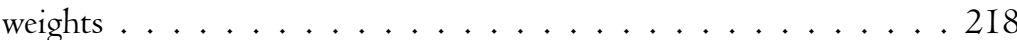

6.4I Fertilizer inputs in $\mathrm{kg} / \mathrm{ha} /$ year for different cultivation areas . . . . 2I8

6.42 Fuel consumption of the different palm oil plantation areas (ton.km/ kg FFB) . . . . . . . . . . . . . 219

6.43 LUC Parameters for different palm oil plantations . . . . . . . . . 220

6.44 Emissions to the atmosphere due to fertilizer application $(\mathrm{kg} / \mathrm{kg}$ of

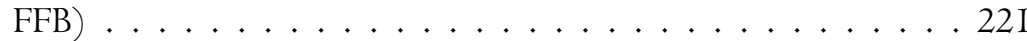

6.45 Water dumping by use of fertilizers . . . . . . . . 22I

6.46 Biodiesel plants and installed capacity . . . . . . . . . . 222

6.47 Average weight of the different palm oil producing companies . . . . 222

6.48 Inputs and energy requirements per IOO tons of FFB . . . . . . . . 224

6.49 Outputs from oil extraction of 100 tons of FFB (ton) . . . . . . . 225

6.50 Properties of the FFB, fiber and shells (\% indicated otherwise) . . . 225

$6.5 \mathrm{I}$ Process Infrastructure of the Palm oil mill plant . . . . . . . . . 226

6.52 Processes description of palm oil refining and biodiesel processing . 227

6.53 Inputs and energy requirements of a palm oil refinery to produce I ton of biodiesel . . . . . . . . . . . . . . . . . 228

6.54 Inputs and energy requirements for the biodiesel plant needed to produce I ton of biodiesel . . . . . . . . . . . . . . 228

6.55 Outputs from the refining oil plant per I ton of oil $(\mathrm{kg}) \ldots . . .228$

6.56 Outputs from the transesterification process per I ton of palm oil biodiesel . . . . . . . . . . . . . . . . . . . . 229

6.57 Transportation distances for palm oil refining and transesterification (in ton $/ \mathrm{km}$ ) . . . . . . . . . . . . . . . . . 229

6.58 Economic value of those by-products from fresh fruit bunches (FFB) 23I

6.59 Energy value of those by-products from FFB (MJ/kg) . . . . . . 23 I

6.60 Fossil fuels production in Colombia (in I000 tons) . . . . . . . . . 236

6.6I Colombian crude reserves and oil production . . . . . . . . 237

6.62 Fuel specification regarding Ecopetrol study . . . . . . . . . . 239

6.63 Crude oil composition from California (including transport and process assumptions from Ecoinvent) . . . . . . . . . . . 240

6.64 Electricity matrix for Colombia ... . . . . . . . . . 24I 
6.65 Emission factors for generation and transmission of electricity used in this study . . . . . . . . . . . . . . . . . . . . 242

6.66 Comparison of $\mathrm{CO} 2$ emissions from fossil fuels from different studies 243

6.67 GHG's emission potential. Different scenarios of sugarcane-based ethanol . . . . . . . . . . . . . . . . . . 259

6.68 GHG's emission potential. Different scenarios of palm oil-based biodiesel per v.km and relative to I00\% fossil diesel . . . . . . . 262

7.I Types of soil suitability defined by FAO. Colors of these different types are reflected in suitability maps. . . . . . . . . . . 273

7.2 Precipitation amount and relationship with the suitability categories described by FAO for biofuel feedstock . . . . . . . . . . . 275

7.3 Temperature suitability across Colombia . . . . . . . . . . . 277

7.4 Matrix to determine climatic suitability . . . . . . . . . . 279

7.5 Flooding-Crop specific classification . . . . . . . . . 28I

7.6 Soil erosion-Crop specific classification . . . . . . . . . . . 283

7.7 Soil depth-Crop specific classification . . . . . . . . . . . . . . 284

7.8 Soil fertility-Crop specific classification . . . . . . . . . . . . 285

7.9 Natural drainage-Crop specific classification . . . . . . . . . . 287

7.I0 Slope-Crop specific classification . . . . . . . . . . . . . . 289

7.I I Matrix to determine agronomic aptitude . . . . . . . . . . . 290

7.I2 Matrix to determine agronomic aptitude (including slope) . . . . . 29I

7.I3 Matrix to determine biophysical aptitude . . . . . . . . . . 29 I

7.I4 Sugarcane: annual yield assumed per every type of suitability . . . 297

7.I5 Palm oil yield assumed per every type of altitude . . . . . . . . . 298

7.I6 Distribution of the carbon reserves above and below ground for Palm

Oil in Sumatra, Indonesia . . . . . . . . . . . . . . 306

7.I7 By-default values for the GIS calculation . . . . . . . . . 3 I8

7.I8 Classification of hydric stress . . . . . . . . . . . . . . 324

7.19 Restriction levels for areas of priority preservation according to SINAP 326

9.I Midpoint and End point indicators for sugarcane-based ethanol and palm oil biodiesel . . . . . . . . . . . . . . . . . 407

9.2 Residuals to the ground by pesticides and fertilizer application

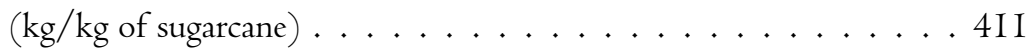

9.3 Entry of residual waters and the production of IOO tons of sugarcane (ton/I00 tons of sugarcane) . . . . . . . . . . 4I6 
9.4 Composition of residual water and treated residual water per $\mathrm{m}^{3}$

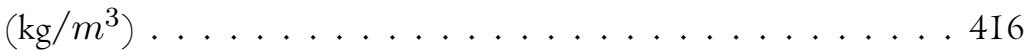

9.5 Methane emissions during residual water treatment . . . . . . . 4 416

9.6 Material inputs for compost per every 100 tons of sugarcane (tons). 4I7

9.7 Mass and compost balance for every 100 tons of sugarcane (average scenario . ........................ 4I7

9.8 Mass and compost balance for every 100 tons of sugarcane (optimized scenario) . . . . . . . . . . . . . . 4I8

9.9 Total residual waters and COD content per IOO tons of treated FFB

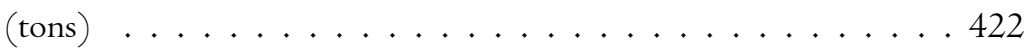

9.I0 Quantity of treated water and methane emissions per 100 tons of FFB (ton) ......................... 422 
